\title{
Immunohistochemical Identification of Factor X-Like Antigen in the A Cells of the Normal Human Pancreas
}

\author{
C. Betterle, A. Trevisan and A. Girolami \\ Istituto di Semeiotica Medica, Padua University Medical School, Padua, Italy
}

\begin{abstract}
Summary. An indirect immunofluorescence technique using two rabbit anti-human factor $\mathrm{X}$ sera was used to investigate the presence of factor $X$ in various human tissues. Of all tissues studied only the cytoplasm of some islet cells of the six human pancreases illustrated specific reacitivity for factor Xlike material. No reaction was seen in the exocrine pancreas. Cross-absorption studies with factor X-deficient plasma, glucagon or $\alpha$-1-antitrypsin did not modify the pattern. On the contrary, cross-absorption with factor X Friuli or with normal
\end{abstract}

plasma eliminated the positivity. No factor X-like material was seen in rat or guinea pig pancreas. The double-immunofluorescence technique demonstrated that the reactivity was localized only in the cytoplasm of the A cells.

Key words: Pancreatic A cell immunohistochemistry, clotting factors, factor $\mathrm{X}$, indirect immunofluorescence technique, double-immunofluorescence technique, glucagonoma, diabetes mellitus, human pancreas.
Factor $\mathrm{X}$ is one of the vitamin K-dependent factors. It is a serine protease, with a molecular weight of about 85,000 dalton, which occupies a pivotal position in the clotting sequence. Once activated by the intrinsic or the extrinsic system, it is capable of promptly converting prothrombin into thrombin in the presence of factor $\mathrm{V}$ and phospholipids.

Data concerning the site of factor $\mathrm{X}$ synthesis are conflicting and limited. In 1966 Olson et al. demonstrated that in the flow from an isolated, perfused rat liver, there was clotting activity due to factor X [1]. A further study failed to confirm these results [2]. Indirect data favouring hepatic synthesis of factor $\mathrm{X}$ are the clotting disorders associated with liver disease and the coumarin-induced clotting defect [3]. The coagulation defect of patients with liver damage is not, however, always attributable to a decreased synthesis of clotting factors, but may be due to intravascular coagulation and/or haemorrhage $[4,5]$. Studies performed until now are therefore based on determination of plasma clotting and/or factor X concentration in blood. There are no histochemical data reported in the literature concerning the localization of this clotting factor in tissues. We have therefore determined factor $\mathrm{X}$ in various human tissues using indirect and double-immunofluorescence techniques.

\section{Materials and Methods \\ Indirect Immunofluorescence Technique}

This technique was performed by the method of Roitt and Doniach [6]. Immediately after the organs were resected during surgery, $0.5-\mathrm{cm}$ blocks of tissue were cut and frozen in iso-pentane which was stored in a mixture of acetone and dry ice. The tissue sample blocks were stored at $-80^{\circ} \mathrm{C}$ until their preparation for study, at which time the blocks were cut in a cryostat into $3.5 \mu$ sections. The following human tissues were used: (a) six histologically normal pancreases of which two were from brain dead-kidney donors and the others were from tissue surrounding insulinomas; (b) one histologically normal ovary removed from a fertile woman with breast cancer, (c) two histologically normal kidney specimens obtained at nephrectomy for hypernephroma, (f) two apparently normal liver samples from two patients with Hodgkin's disease, (g) two normal liver samples, (h) gastric corpus from three patients with duodenal ulcer, (i) two normal skin specimens taken from the site of surgical incisions and (j) two specimens of normal thyroid.

We used the following unconjugated and conjugated sera: antihuman factor X rabbit serum was furnished by Dr. D. Aronson (National Institutes of Health, Bethesda, Maryland, USA). It was used in its undiluted state and also in serial dilutions to the end point. When tested by cross-over electrophoresis this serum demonstrated principally anti-factor $X$ activity, and secondarily a slight anti- $\alpha$-1-antitrypsin activity [7]. Another anti-human factor $X$ serum was supplied by Drs. S. S. Shapiro, P. Thiaparajan and L. De Marco (Cardeza Foundation, Jefferson Medical College, Philadelphia, USA). It was used in its undiluted form and in serial dilutions to the end point. The serum was obtained by immunizing rabbits with highly purified factor $X$ extracted from normal human plasma pools. The cross-over electrophoresis of this serum with pooled normal human plasma showed a single band of precipitation which was not visible with plasma from a patient with a serious defect of factor X. Anti-factor VIII rabbit serum (Behring Institut, Marbourg, FRG) and an anti-rabbit gamma globulin goat serum which was fluorescein-conjugated (Behring Institut, Marburg, FRG) were also used, at a dilution of a $1: 20$.

Cryostat sections of the different tissues were first incubated for $2 \mathrm{~h}$ with unconjugated sera, then washed in phosphate buffered saline solution (PBSS), and incubated with conjugated serum for $1 \mathrm{~h}$ at room temperature. After further washing with PBSS the specimens were mounted for microscopic examination. Control tests were performed by substituting anti-factor X sera with PBSS and by substituting human pancreas with rat and guinea pig pancreas. Five rats and five gui- 
nea pigs were killed by exsanguination under diethyl ether anaesthesia. The animal pancreases were divided into head, body and tail and every specimen was treated as described above.

\section{Absorption Studies}

The anti-factor $X$ sera were absorbed with the following substances: (a) pooled normal human plasma, (b) plasma from a patient with abnormal factor X (factor X Friuli) which showed a normal factor X antigen and low factor $\mathrm{X}$ activity as demonstrated by tissue thromboplastins $[8,9]$, (c) plasma from a patient with severe congenital factor $\mathrm{X}$ deficiency (activity and immunoreactivity $<1 \%$ of normal) [10], (d) lyophilized glucagon (Novo Industri, Denmark), (e) lyophilized human $\alpha$-1-antitrypsin (Sigma Chemicals, St. Louis, USA), (f) factor $\mathrm{X}$-deficient plasma followed by $\alpha$-1-antitrypsin and glucagon, and (g) glucagon followed by $\alpha$-1-antitrypsin. Aliquots of factor $\mathrm{X}$ antisera were incubated separately with substances (a), (b), (c), or (f) in proportion $1: 10(\mathrm{v}: \mathrm{v})$, or with the lyophilized substances $(\mathrm{d}),(\mathrm{e}),(\mathrm{f})$ or $(\mathrm{g})$, in the proportion $1 \mathrm{ml}: 50 \mathrm{mg}$. After incubation for $12 \mathrm{~h}$ at $4^{\circ} \mathrm{C}$ and $1 \mathrm{~h}$ at $37^{\circ} \mathrm{C}$, the sera were ultracentrifuged at $200,000 \times \mathrm{g}$ for $30 \mathrm{~min}$ in a Spinco L50 ultracentrifuge. The supernatants were tested in serial dilutions to the end point on pancreatic sections by indirect immunofluorescence. Each absorption was carried out at least three times and each supernatant was tested four times.

\section{Double-Immunofluorescence Technique}

This technique was performed on cryostat sections of all normal human pancreas specimens using the following antisera: (a) rabbit antifactor X serum, (b) human serum with glucagon-cell autoantibodies described previously [11], (c) human serum with somatostatin-cell autoantibodies supplied by Dr G.F. Bottazzo (Department of Immunology, The Middlesex Hospital, London, UK) [12], (d) anti-rabbit IgG goat serum conjugated with rhodamine (Cappel Laboratories, Cochranville, PA, USA) diluted $1: 40$, and (e) F(ab)2 goat serum antihuman immunoglobulins conjugated with fluorescein diluted $1: 40$. The same section was incubated with rabbit serum followed by rhodamine-conjugated anti-rabbit goat serum then either with human glucagon-cell autoantibody or with human somatostatin-cell antibody followed by fluorescein-conjugated goat serum anti-human immunoglobulins.

In each experiment the human serum was applied first to exclude blocking phenomena. To exclude possible inter-species reactions the sections were stained with one of the unconjugated sera followed by both rhodamine- and fluorescein-conjugated sera. The technique was performed on histologically normal human pancreas tails and bodies from two brain-dead kidney donors and from four patients with insulinoma.

The slides were read using a Leitz Orthoplan microscope equipped with a $100 \mathrm{~W}$ HBO lamp. BP $470-490$ and LP 515 filters were used for fluorescein, while BP 530-560 and LP 580 filters were used for thodamine. Each section was studied using red and green filters, both visually and by double exposure photomicrography on Kodak Ektachrome colour film (200 ASA).

\section{Results}

\section{Indirect Immunofluorescence Technique}

Bright-green cytoplasmic fluorescence was observed on most cells scattered around the entire periphery of the pancreatic islet using anti-factor $\mathrm{X}$ sera. In addition finger-like projections of cells radiated toward the centre. This pattern generally prevailed for each islet studied with only minor staining differences involving the distribution and number of cells. More cells were stained in those samples taken from the tail of the pan-
Table 1. Absorption studies of anti-factor $X$ sera

Absorbing substances

Immunofluorescence on human islets

Pooled normal human plasma

Factor X Friuli plasma

Factor $\mathrm{X}$ deficient plasma

Glucagon

$\alpha$-1-antitrypsin

Glucagon and $\alpha$-1-antitrypsin

Factor $\mathrm{X}$ deficient plasma, glucagon and $\alpha$-1-antitrypsin

Different aliquots of anti-factor X sera were incubated separately with the absorbing substances at least three times and after ultracentrifugation the supernatants were tested four times, by indirect immunofluorescence, on unfixed cryostat sections of normal human pancreases

creas (Fig. 1) than in those samples taken from the body of the pancreas (Fig.2). All human pancreas samples obtained from patients with insulinoma or from braindead kidney donors gave similar results. This reaction was seen with anti-factor $X$ sera up to a dilution $1: 320$. No staining was observed in the exocrine portion of the gland, nor in any other human tissue. No staining was observed when the tests were performed by substituting anti-factor X sera with PBSS or by substituting human pancreas with rat and guinea pig pancreas. A bright endothelial fluorescence was seen in all human tissues using anti-factor VIII serum.

\section{Absorption Studies}

The fluorescence pattern of the human pancreatic isletcells did not change after absorption of the anti-factor $\mathrm{X}$ sera with factor $\mathrm{X}$ deficient plasma, glucagon, $\alpha-1$ -antitrypsin, combined factor X-deficient plasma with $\alpha-1$-antitrypsin and glucagon, combined glucagon and $\alpha$-1-antitrypsin. The reaction was positive with absorbed anti-factor $X$ sera up to a dilution $1: 320$. No fluorescent pattern was visible after absorption of anti-factor X sera with pooled normal human plasma or factor $\mathrm{X}$ Friuli plasma (Table 1).

\section{Double-Immunofluorescence Technique}

Viewing the islet with filters for rhodamine (red) and fluorescein (green) after incubation with rabbit anti-factor $\mathrm{X}$ sera, human serum with glucagon-cell autoantibodies, anti-rabbit rhodamine and anti-human fluorescein-conjugated sera, we found that the cells coloured red were the same as those coloured green. This observation was confirmed by double exposure photomicrography (Fig. 3A and B).

Under the same filtering conditions using rabbit anti-factor X sera, human serum with somatostatin-cell autoantibodies, anti-rabbit rhodamine and anti-human fluorescein-conjugated sera, we observed that the red coloured cells were different from the green ones. Double exposure photomicrography confirmed this ob- 
servation. This technique gave identical results in all human pancreas samples studied. In control studies no interspecies cross-reactions or blocking phenomena were observed (Fig. 4A and B).

\section{Discussion}

The indirect immunofluorescence technique is a method currently used to identify tissue antigens using specific antisera [6]. This technique allowed, for example, the identification of factor VIII in the endothelium [13-15] and in platelets [16]. This study illustrates that both types of anti-factor $\mathrm{X}$ sera used react with cyto- plasmic antigens in normal human pancreatic islet-cells, while these sera do not react with either hepatocytes or the other tissue cells studied. The distribution of the cells binding anti-factor $\mathrm{X}$ sera strongly resembled the distribution of the A cells as described by Orci and Unger $[17,18]$. A double-immunofluorescence technique was used to identify the antigen-containing cells. As $A$ and D cell markers we used two human sera with marked reactivity for these cells [11,12]. This method allowed us to demonstrate that the A cells were the only pancreatic cells which contained factor $\mathrm{X}$ or the factor $\mathrm{X}$-like material. We tested the specificity of our anti-factor X sera by absorption studies. The lack of reaction after absorption of factor $\mathrm{X}$ antisera with pooled nor-
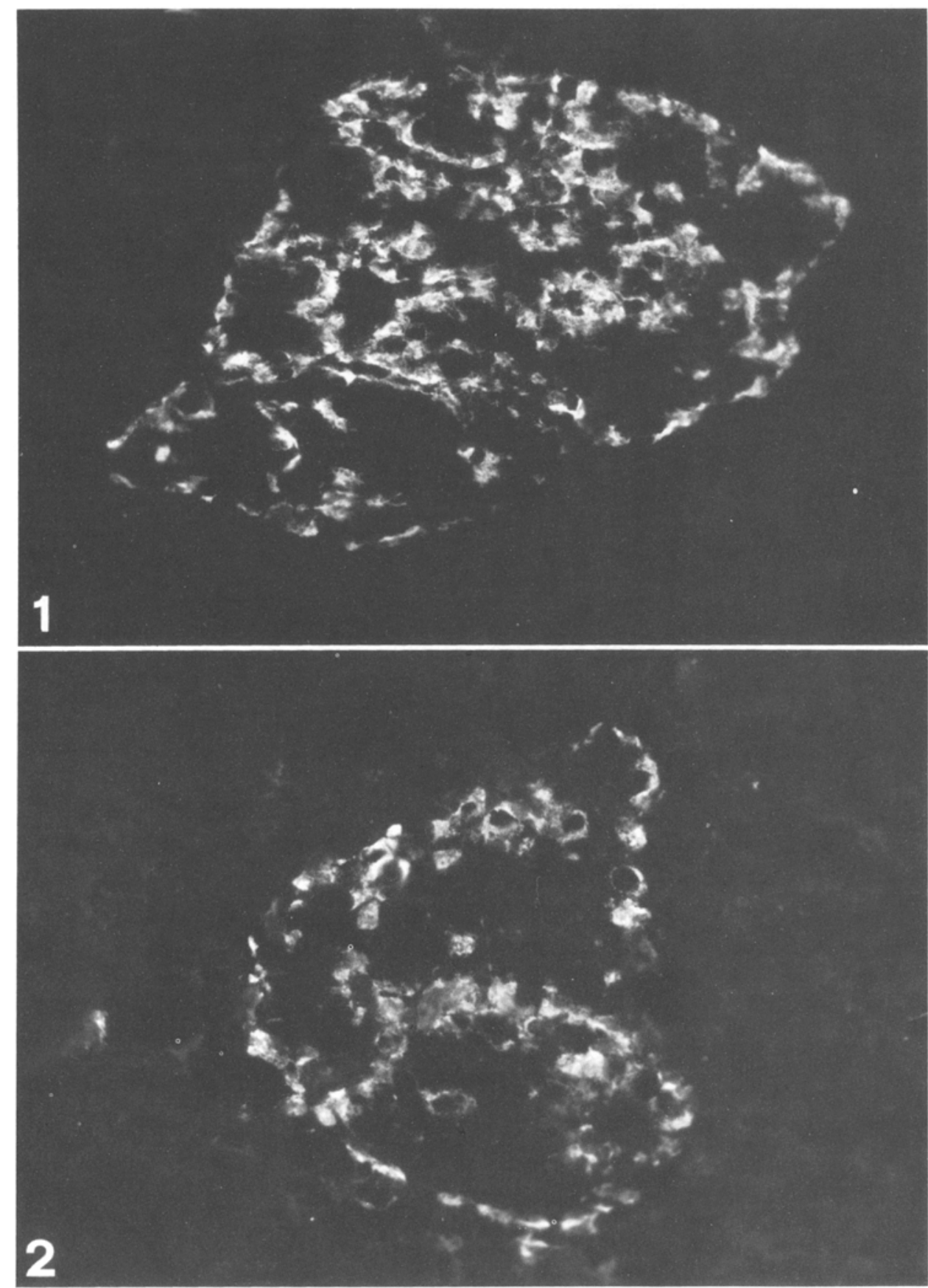

Fig. 1. Human pancreas (tail) from brain-dead kidney donor. Cells containing factor X-like immunoreactivity scattered around the periphery and in finger-like projections radiating towards the centre of an islet $(\times 400)$
Fig. 2. Human pancreas (body) from brain-dead kidney donor. Cells containing factor X-like immunoreactivity scattered predominantly around the periphery of the islet. The number of stained cells is clearly less than that present in an islet of the tail $(\times 400)$ 

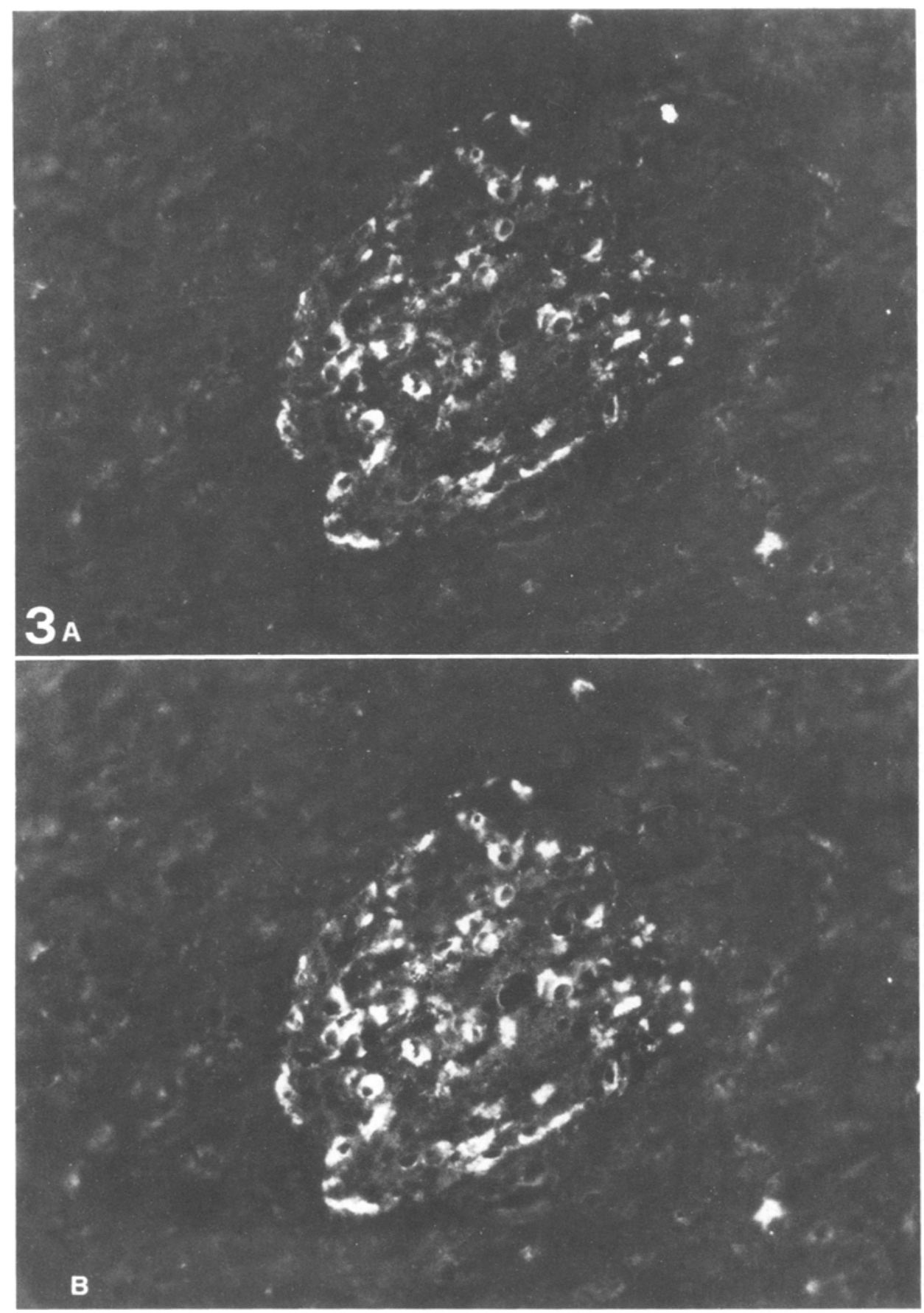

Figs. 3 A and B. Human pancreas stained by double immunofluorescence technique to demonstrate that the cells containing factor X-like immunoreactivity are A cells. A Human serum with glucagon-cell autoantibodies counterstained with fluorescein-conjugated goat anti-human immunoglobulin showing reactive cells in an islet of Langerhans (original photo green $)(\times 250)$.

B Same islet stained with rabbit antifactor X serum counterstained with rhodamine-conjugated goat antirabbit IgG. The pattern of reactive cells is identical to that given by human serum with glucagon-cell autoantibodies (original red) $(\times 250)$ mal human plasma or with factor X Friuli plasma and the persistence of reaction after absorption with severely factor X-deficient plasma demonstrated that these sera identified an antigen at the level of $A$ cells that was either factor $\mathrm{X}$ or a substance cross-reacting with factor X.

The antigens identified so far in human and rat A cells by means of immunohistochemical methods are: glucagon [17-19], glicentin [18, 19], cholecystokinin-pancreozymin [20], gastric inhibitory polypeptide [21-23]. Endorphin-like antigens have been identified in rat A cells [24]. In guinea pig A cells, glicentin [19] and gastric inhibitory polypeptide [23] have been demon- strated. However, there was no reaction using a specific anti-glucagon serum [19]. We would like to point out, however, that Patzelt et al. have suggested that proglucagon may contain immunodeterminants of all the different peptides immunologically detected in the A cells [25]. Finally $\alpha-1$-antitrypsin has also been found in human A cells [26]. Our sera still reacted after absorption with glucagon and $\alpha$-1-antitrypsin. This demonstrated that the serum reactivity was not due to the presence of a cross-reactivity against glucagon or $\alpha$-1-antitrypsin. The fact that sera reacted with human but not with rat and guinea pig pancreas excluded cross-reactivity with glicentin, cholecystokinin-pancreozymin, 

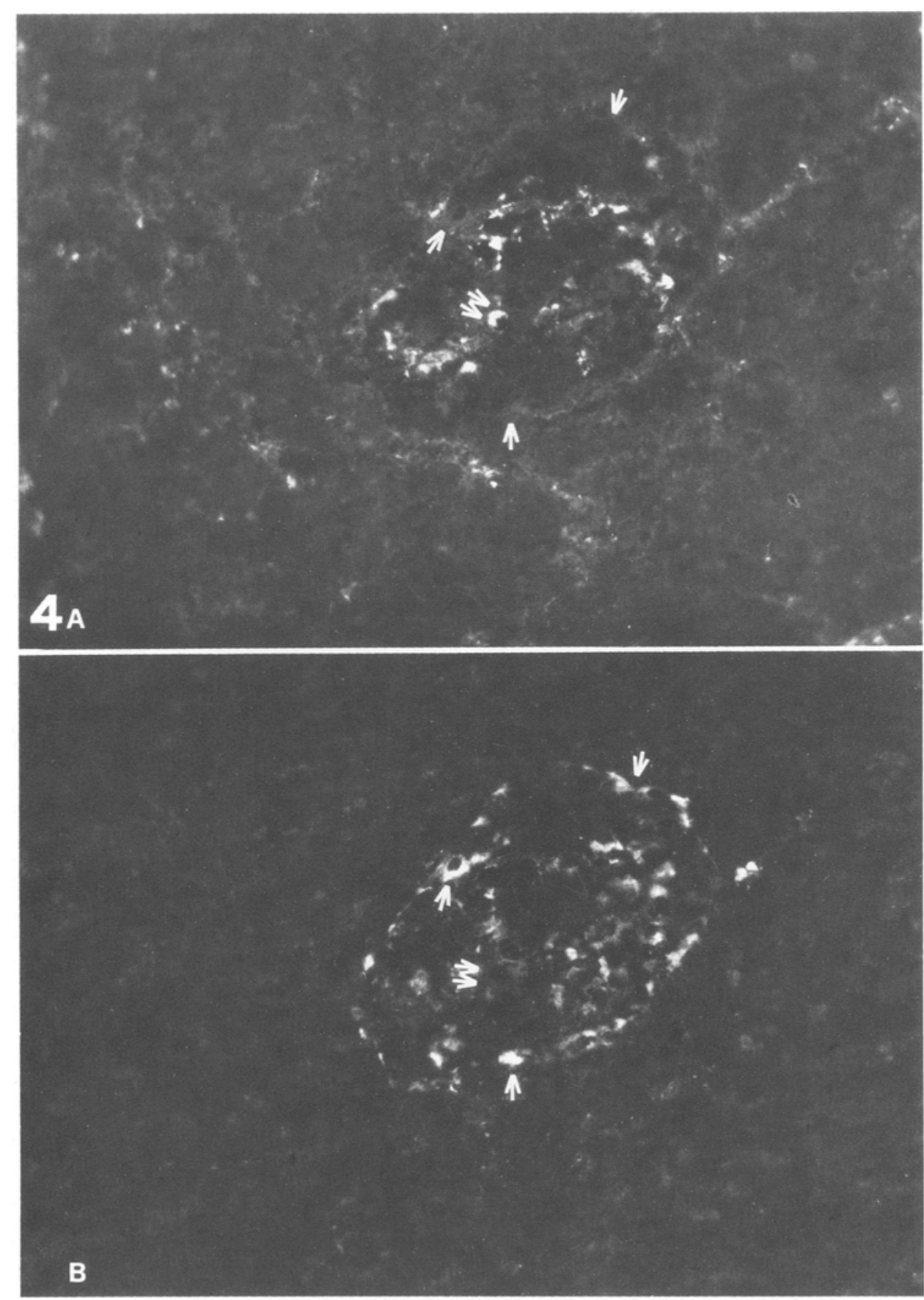

Figs. $4 \mathrm{~A}$ and $\mathrm{B}$. Human pancreas stained by double immunofluorescence technique to demonstrate that the cells containing factor X-like immunoreactivity are not $D$ cells.

A Human serum with somatostatincell autoantibodies counterstained with fluorescein-conjugated goat anti-human immunoglobulin showing few reactive cells in an islet of Langerhans (original photo green) ( $\times 250)$. B Same islet stained with rabbit anti-factor $X$ serum counterstained with rhodamine conjugated goat anti-rabbit IgG (original photo red). The pattern of reactive cells is different from that given by human serum containing somatostatin-cell autoantibodies $(\times 250)$

$\uparrow$ : cells stained by anti-factor $X$ serum but negative with somatostatincell autoantibodies.

$\uparrow \uparrow$ : cells fluorescent with somatostatin-cell autoantibodies but negative with anti-factor $\mathrm{X}$ serum gastric inhibitory polypeptide, endorphin or proglucagon.

The evidence presented in this study strongly indicates that human pancreatic A cells contain a factor Xlike antigen. However, until now we have not had the opportunity to study non-pancreatic cells containing glucagon-like immunoreactivity. The discovery that the A cell antigen in question was actually factor $\mathrm{X}$ was unexpected, and not previously reported. Earlier studies concentrated on a hepatic site of factor X production, but results were conflicting $[1,2]$. In the light of these new data, the primary role of the liver in factor X synthesis must be reconsidered. Since we found factor $\mathrm{X}$ only in the A cells and not in the hepatocytes, we hypothesize that the A cells may synthesize a factor X precursor which could reach the liver via the portal circulation and become modified there through the action of vitamin $\mathrm{K}$. The lack of reaction in the four liver samples tested could be due to the fact that hepatocytes rapidly release the 'completed' factor X into the circulation.

The presence of factor X in A cells could explain the high incidence of thrombo-embolism in the evolution of glucagonoma [27-29]. The glucagonoma, as well as producing excessive quantities of glucagon, could also produce excessive quantities of factor $X$ which would explain the high incidence of thrombo-embolism. Thus, 
increased factor X levels in the plasma could be a new diagnostic sign of this tumour. Unfortunately, we have not had the opportunity to study patients with this disease.

It is also worth mentioning that increased levels of factor X have been reported in insulin-dependent diabetic patients [30]. It has been suggested that the A cells of diabetic patients are hyperfunctioning and this may be expressed as a relative or absolute hyperglucagonaemia [31-35]. In the light of the results reported here we think that hyperglucagonaemia and increased levels of factor $\mathrm{X}$ in diabetic patients may be related. Thus, we suggest that factor $\mathrm{X}$ may be considered a normal constituent of the pancreatic human A cell along with the other substances already specifically identified there such as glucagon [17-19], glicentin [18, 19], $\alpha$-1-antitrypsin [26], cholecystikinin-pancreozymin [20] and gastric inhibitory polypeptide [21-23].

Acknowledgements. We wish to express our gratitude to Mr B. Pedini and $\mathrm{Mr}$ D.Stocco for valuable technical assistance. This study was partially supported by Grants from the M.P.I., Rome (1592-1979) and from the Venetian Regional Government, Venice.

\section{References}

1. Olson JP, Miller LL, Troup SB (1966) Synthesis of clotting factors by the isolated perfused rat liver. J Clin Invest 3:690-701

2. Dodds WJ (1969) Storage, release and synthesis of coagulation factors in isolated perfused organs. Am J Physiol 3: 879-883

3. Williams WJ (1977) Production of plasma coagulation factors. In: Williams WJ, Beutler E, Erslev AJ, Rundles RW (eds) Hematology. McGraw-Hill, New York, pp 1250-1258

4. Nossel HL (1977) Acquired coagulation disorders. In: Thorn GW, Adams RD, Braum E, Isselbacher KJ, Petersdorf RG (eds) Harrison's principles of internal medicine. McGraw-Hill, New York, pp1724-1725

5. Rapaport SI (1977) Defibrination syndromes. In: Williams WJ, Beutler E, Erslev AJ, Rundles RW (eds) Hematology. McGrawHill, New York, pp 1454-1480

6. Roitt IM, Doniach D (1969) Manual of autoimmune serology. WHO Geneva

7. Girolami A, Sticchi A, Bareggi G (1972) Cross-over electrophoresis (electrosyneresis) visualization of the abnormal factor X (factor X Friuli). J Lab Clin Med 80: 740-747

8. Girolami A, Molaro G, Lazzarin M, Brunetti A, Scarpa R (1970) A new congenital haemorrhagic condition due to the presence of an abnormal factor X (factor X Friuli). Study of a large kindred. Br J Haematol 19: 179-192

9. Girolami A, Bareggi G, Borsato N (1975) Factor X Friuli and immunological study in plasma and in serum using several methods. Blut 30: 203-213

10. Girolami A, Caser P, Brunetti A, Prinoth G (1975) Classical factor X deficiency. A report of another case. Acta Haematol 53: $118-125$

11. Del Prete GF, Tiengo A, Nosadini R, Bottazzo GF, Betterle C, Bersani G (1978) Glucagon secretion in two patients with autoantibodies to glucagon-producing cells. Horm Met Res 10: 260-261

12. Bottazzo GF, Lendrum R (1976) Separate autoantibodies to human pancreatic glucagon and somatostatin cells. Lancet 2: 873-876

13. Hoyer LW, de los Santos RP, Hoyer JR (1973) Antihemophilic factor antigen. Localization in endothelial cells by immunofluorescence microscopy. J Clin Invest 52:2737-2744

14. Bloom AL, Giddins JC, Wilks CJ (1973) Factor VIII on the vascular intima: possible importance in hemostasis and thrombosis. Nature New Biology 241: 217-219
15. Gruson R, Rizza R (1974) Factor VIII-related antigen in tissue detected by the indirect immunofluorescence technique. Blut 29 : 241-249

16. Betterle C, Fabris F, De Marco L, Del Prete GF, Girolami A (1977) Clotting factor and platelets. Immunofluorescence evidence that fibrinogen and factor VIII are present in human washed platelets, whereas prothrombin complex factors and factor XIII are lacking. Haemostasis 6: 171-179

17. Orci L, Unger RH (1975) Functional subdivision of islet of Langerhans and possible role of D cells. Lancet 2: 1243-1244

18. Unger RH, Orci L (1981) Glucagon and the A cell. Physiology and pathophysiology. N Engl J Med 304: 1518-1524

19. Ravazzola M, Siperstein A, Moody AJ, Sundby F, Jacobsen H, Orci L (1979) Glicentin immunoreactive cells: their relationship to glucagon-producing cells. Endocrinology 2: 499-508

20. Grube D, Maier V, Raptis S, Schlegel W (1978) Immunoreactivity of the endocrine pancreas. Evidence for the presence of cholecystokinin-pancreozymin within the A-cell. Histochemistry $56: 13-35$

21. Smith PH, Merchant FW, Johnson DG, Fujimoto WY, Williams RH (1977) Immunocytochemical localization of a gastric inhibitory polypeptide-like material within A-cells of the endocrine pancreas. Am J Anat 149: 585-590

22. Smith PH, Merchant FW, Johnson DG, Fujimoto WY, Williams RH (1977) Immunocytochemical localization of gastric inhibitory polypeptide in the pancreatic islet A-cells of rats and humans. Anat Rec 187: 717

23. Alumets J, Hakanson R, O'Dorisio T, Sjölund K, Sundler F (1978) Is GIP a glucagon cell constituent? Histochemistry 58:253-257

24. Grube D, Voigt KH, Weber E (1978) Pancreatic glucagon cells containing endorphin-like immunoreactivity. Histochemistry 59 ; 75-79

25. Patzelt C, Tager HS, Carroll RJ, Steiner DF (1979) Identification and processing of prolucagon in pancreatic islets. Nature 282: 260-266

26. Ray MB, Desmet VJ, Gepts W (1977) Alpha-1-antitrypsin immunoreactivity in islet cells of adult human pancreas. Cell Tiss Res 185: 63-68

27. Pedersen NB, Jonsson L, Holst JJ (1976) Necrolytic migratory erythema and glucagon cell tumour of the pancreas: the glucagonoma syndrome. Acta Dermatovener (Stockholm) 56: 391-395

28. Holst JJ (1978) Glucagonomas. In: Bloom SR (ed) Gut hormones. Churchill Livingstone, Edinburgh London New York, pp 599-604

29. Lokich J, Anderson N, Rossini A, Hadley W, Federman M, Legg M (1980) Pancreatic alpha cell tumors: case report and review of the literature. Cancer 45:2675-2683

30. Fuller JH, Keen H, Jarrett RJ, Omer T, Meade TW, Chakrabarti R, North WRS, Stirling Y (1979) Haemostatic variables associated with diabetes and its complications. Br Med J 2:964-966

31. Unger RH, Aguilar Parada E, Muller WA, Eisentraut AM (1970) Studies of pancreatic alpha cell function in normal and diabetic subjects. J Clin Invest 49: 837-848

32. Unger RH (1971) Glucagon physiology and pathophysiology. N Engl J Med 285: $443-449$

33. Unger RH, Orci L (1975) The essential role of glucagon in the pathogenesis of diabetes mellitus. Lancet 1:14-16

34. Unger RH, Orci L (1977) The role of glucagon in the endogenous hyperglycemia of diabetes mellitus. Ann Rev Med 28: 119-130

35. Tiengo A, Del Prete GF, Nosadini R, Betterle G, Garotti C, Bersani $G$ (1977) Insulin and glucagon secretion in diabetic and non-diabetic patients with circulating islet-cell antibodies. Diabetologia 13: $451-458$

Received: 21 September 1981

and in revised form: 23 February 1982

\section{Dr. C. Betterle}

Istituto di Semeiotica Medica

Padua University

Via Ospedale Civile 105

35100 Padua, Italy 